\title{
Antisemitism and Related Expressions of Prejudice in a Global World: A View from Latin America
}

\section{Introductory Reflections}

Antisemitism has acquired complex dynamics; its recurrences and transformations appear differentially over global interconnected realms, mediated by shared regional traits and distinct local configurations. Thus, the current international and transnational scenario, characterized by the unexpected revival of old antisemitic expressions and the rise of new ones, calls for an analysis of both the specific and the common traits. Due to its global character, which remains anchored in diverse local realities, it is vital to avoid abstract universalisms that could dilute space, actors, and societies' specificity.

Antisemitism and its different ideological matrices are subjective (stereotypes, myths, attitudes) and behavioral (actions, practices, institutional arrangements); agency and structure meet. The intellectual corpus that nourishes ideological frameworks and theoretical formulations interacts with socio-political processes and praxis. The imaginaries that nourish direct discourses and practices have been built on mobilizing myths that strengthen their routes by opposing the negative identification of Jewish Otherness as the radical outsider or enemy of the collective, be it society, the nation, or the state.

Latin America stands out with its inner diversity and singularities but not in isolation from other countries and regions of the world. While the focus on antisemitism in Latin America may not be surprising given its historical legacy and foundational experience, simplistic and reductionist approaches to the region should be avoided and instead replaced by more analytical ones, showcasing differences in time, place, and forms of expression and its relation to changing contexts: from the Conquest and the Inquisition to nation-building and the search for national integration; the Western world as the origin and as a referent to follow or oppose: the early translation of antisemitism without Jews; politicized ethnicities; contradictory efforts to build and reach modernity, displayed

Note: Some sections of this article had a previous version in J. Bokser Liwerant and Y. Siman, "Antisemitism in Mexico and Latin America: Recurrences and Changes," in Antisemitism in North America: New World, Old Hate, ed. S. K. Baum et al. (Leiden: Brill, 2016), 21-173.

Ә OpenAccess. ( 2022 Judit Bokser Liwerant, published by De Gruyter. (cc) BY-NC-ND This work is licensed under the Creative Commons Attribution-NonCommercial-NoDerivatives 4.0 International License. 
between multiple modernities ${ }^{1}$ and the mausoleum of modernities; ${ }^{2}$ nationalism and its bifurcations, peripheral nationalism and its exclusionary dimensions; fascism vis-à-vis liberalism and its neutral spheres; the place and role of the Catholic Church and Catholicism as a civic religion; from globality to the contradictory impact of globalization; from the Third World to the post-colonial Global South; from the search for modernity to its radical critique. And, still, a substantive chain well into the twenty-first century: populism; dissolvent democracies; democratization and de-democratization; the redefinition of globality and regional alliances.

Particular attention must be paid to its historical socio-political expressions and its symbolic representations. Indeed, antisemitism's symbolic and conceptual representations and how they are discursively formulated, repeated, reelaborated, and transmitted pose new challenges to social research. ${ }^{3}$ The building of the negative tropos of the Jew and its changing role and functionality run across time and distinctive social, economic, political, and cultural constellations.

Antisemitism's configuration is based on equal/different tropos as thematic fields displayed interactively, which create a habitus. According to Bourdieu, habitus refers to principles connecting a unitary field; they are classification schemes that work as distinctive signs of one symbolic capital. ${ }^{4}$ Conservatives, liberals, religious, secular, Right, Left: different camps and overlapping motives reveal several less obvious social and political currents and cultural traits. Its different ideological matrices thus interact.

An analysis of contemporary antisemitism accounts for multiple timeline connections among particular individual and collective actors, ideas, and symbols through different circuits and levels. A multidimensional and transnational perspective shall contribute to robust explanations of its meanings, structural manifestations, and expression modes. The historical changing shades, shapes, and meanings of negative conceptual images of Jews, the recurrences of original stereotypes and prejudices, and their shifting significance on the one hand, and the overlapping of new expressions at the meaning-making level on the other, provide a fertile field for its analysis.

1 Cf. S. N. Eisenstadt, “Multiple Modernities,” Daedalus 129, no. 1 (2000): 1-29.

2 Cf. L. Whitehead, "Latin America as a 'Mausoleum of Modernities'," in Latin America: A New Interpretation, ed. L. Whitehead (New York: Palgrave Macmillan US, 2006), 23-68.

3 Cf. M. Reisigl and R. Wodak, Discourse and Discrimination: Rhetorics of Racism and Antisemitism (London: Routledge, 2005).

4 Cf. P. Bourdieu, Razones prácticas: Sobre la teoría de la acción (Barcelona: Anagrama, 2007). 
Indeed, antisemitism's symbolic and conceptual representations and how they are produced and reproduced discursively pose renewed challenges to social research.

This article builds on snapshots of negative Jewish tropos-building, the avatars of negative representation and stereotypes of Jews in Latin America, with a global perspective. Historic recurrences and changes and their different referents of collective belonging-culture, ethnicity, language, religion, nation, and culture-will be analyzed in paradigmatic contextual scenarios, differing sources, and currents. In its specificity and its interactions with related prejudices, negative tropos-building will be seen at different levels. Given the historical pattern of recurrence and change, the non-linearity and complexity of the interactions and mutual influences between antisemitism and related prejudices will be analyzed. We will emphasize theoretical formulations and conceptual approaches, focusing specifically on the interaction between antisemitism, antiIsraelism, and anti-Zionism as singular yet overlapping phenomena at the meaning-making level. Its discursive production and material projection, as well as its dual physical and symbolic links with violence, concern society, culture, and the public and civic sphere, where discourse and interpretation meet, and vocabularies connect images and representations while shaping prejudices.

\section{Recurrences and Changes}

The historical recurrence of antisemitism and its discursive production does not mean witnessing the same phenomenon. It may bring back old elements while acquiring new expressions or introducing new ones, responding to different logics and functions and framed by distinct individuals and groups. In this sense, one problem with the "Hydra" explanation-the monster always lurking under the surface of the water and revealing its many heads in other places and times-is its ahistorical conception of the various expressions of antisemitism. Indeed, like geological layers, while each form draws on and replicates older forms,

they are also different phenomena. They arise and they become widespread in radically different times and places. They have different manifestations, are employed by different social forces, they make use of other narratives. [...] the difference between a time or a place where it is visible and one where it is not is purely contingent. ${ }^{5}$

5 D. Hirsh, “Anti-Zionism and Antisemitism: Cosmopolitan Reflections," Occasional Papers (Yale Initiative for the Interdisciplinary Study of Antisemitism [YIISA], New Haven, 2007), 19-21. 
Similar to other discriminatory social processes, it may be veiled, diffuse and structural, latent or manifest. The recovery and elaboration on previous representation and images may be better understood as a constellation of attitudes, stereotypes, and prejudices, conceptual legacies that overlap. A realm of ideologies and theories: world visions and conceptualizations. Its practical behavior implies acts, praxis, institutional orders, and structural configurations. It has indeed displayed a wide range of expressions: hostile behavior and physical aggression against individuals and communities, actions against specific persons ranging between harassment, physical violence, the extreme of murder, the racialization of a people, and the Holocaust.

Not the Hydra, then, but tropos and representations that relate to the Jews and Jewishness's imaginations, were built throughout history by discursive elements. ${ }^{6}$ Different times and ideological matrices that nourish direct discourses and practices have been constructed on mobilizing myths that strengthen the view of Jews as the radical outsiders.

Tropos indicate metaphors that objectify antisemitic imagination-a deicidal people, composed of money-grubbers and money lovers; rich, powerful, selfish, immoral; alien, un-rooted; an exclusive caste, a distinct racial character; Jewish World domination; world conspiracy; the Zionist lobby; Zionism equated to racism; Israel and Zionism-the matrix power of colonialism. Simultaneously, antisemitism has multiple connections with other processes and trends-currents and countercurrents-amidst complex social dynamics of acceptance and rejection.

Thus, tropos-building leads to a diachronic perspective amidst changing socio-political and cultural constellations. Latin America has different codes of inclusions and exclusions. The rejection and absence of collective actors as legitimate inhabitants of the public sphere have been built and narrated differently. In the Southern cone, in Euro-American countries, where mass migration modified the population profile, it took shape in an alleged neutral public sphere visà-vis private differences, which was the idea of secular, liberal thought, of a national identity constructed on the supposedly integrating foundations that homogeneity provides. The national subject was not understood in its diversity; the Latin American liberal narrative turned its back to the latter. In IndoAmerica, diversity remained a referent and bastion for the indigenous peoples, who became the essential national subject and the sole dweller of Otherness. Together with them, immigrant minorities emerged as a fenced-off duo. In both

6 Cf. S. DellaPergola, "Jewish Perceptions of Antisemitism in the European Union, 2018: A New Structural Look,” Analysis of Current Trends in Antisemitism - ACTA 40, no. 2 (2020): 1-86. 
constellations, the process of national building found difficulties facing the collective Jewish condition.

Whereas the Western program of modernity constituted a crucial and critical referent for Latin American societies, they developed distinctly modern singular models and paths concerning their cultural premises, traditions, and historical experiences. Sustained global dynamics developed through a peripheral connection to external centers that provided the parameters of institutional creation and conceptions of the nation. ${ }^{7}$ Being part of the West but simultaneously differing from it shaped many values and institutional arrangements as cultural hybrids. While religion has been structurally embedded in social life, Catholicism's internalization also implied its conversion into civic culture. Profound paradoxes developed: civic Catholicism opened the possibility of creating new meanings and codes, thus advancing secularization in the public sphere. However, it simultaneously sets its limits. The Catholic Church's central place enhanced difficulties when dealing with religious and ethnic diversity, thereby projecting encounters with Otherness as contradictory realities of social diversity and homogeneous goals and narratives. Ethnicity and religion have public significance, and nationalism has not displayed secular civic inclusiveness. Nationalism and politicized ethnicity, as characteristically modern phenomena, have been subject to chronic challenges in the region.

Convergences and divergences between opposites framed the encounter with Jews. Their ethnonational diaspora character, as a socio-cultural formation, was perceived as an anachronistic, unacceptable realm of alterity; its members were suspected of not having been assimilated or fully integrated. This issue has been part of modernity's European configuration, and it is also the case in Latin America. Even in the absence of Jews, the struggles of liberals and conservatives carried anti-Jewish arguments, nourishing their negative representation.

One among the foundational examples of the various nationalist/antiforeigner tones that were expressed along the continent may be seen in Mexico, in the universal hatred the Revolutionaries (1910) aimed at the technocratic elite of Porfirio Díaz's dictatorship (1884-1910), the so-called científicos (scientists). The anti-cientifico discourse took the shape of antisemitic ideology, even though there were no Jews in the group, and set the tone of revolutionary nationalism that would ultimately get institutionalized. The "traitor within" image generated

7 Cf. S. N. Eisenstadt, "Latin America and the Problem of Multiple Modernities," in Shifting Frontiers of Citizenship: The Latin American Experience, ed. M. Sznajder, L. Roniger, and C. Forment (Leiden: Brill, 2013), 43-54; J. Bokser Liwerant, “Thinking Multiple Modernities from Latin America's Perspective: Complexity, Periphery and Diversity," in Varieties of Multiple Modernities: New Research Design, ed. G. Preyer and M. Sussman (Leiden: Brill, 2016), 177-205. 
fears as diffuse and widespread as the support for capitalist development, stability, and progress that defined the regime. The traitor's association with cosmopolitanism and finance made antisemitic rhetoric politically viable. On the eve of the outbreak of the Revolution, consensus on this matter was such that revolutionaries like Luis Cabrera had no qualms about calling the científicos avatars of the eternal Jew. They, he argued, were of neither the conservative nor the reformist/liberal party. "Rather, they belonged to the cowardly and calculating group that sides opportunistically with whomever is in power to further their financial interests." No loyalties, only selfishness and materialism. ${ }^{8}$ Forged in the Dreyfus Affair furnace, and at the time of the United States' rise as the hegemon in the Americas, anti-cientifico rhetoric adopted the Jew-fetishism that had been emerging in Europe since the mid-nineteenth century and used it to rally a variety of constituencies. As an example of modern antisemitism, the anti-científico sentiment was unusual in two respects: it targeted symbolic, rather than literal, Jews; and it developed in a context of growing economic dependency, rather than in the transition from nationalism to imperialism, as was the case in France and Germany. ${ }^{9}$ The Affair became an integral part of conservatives/liberals confronting the church and the military's role and place. Known prejudices constituted early contents of the negative tropos.

Antisemitism, historically, has been nourished by religious beliefs, myths, socio-economic motives, xenophobic sentiments, and racism. The latter is not exclusively associated with biological inferiority but has recently extended to a cultural version that implies veiled attitudes against national, ethnic, and religious groups, especially minorities, thereby isolating and segregating them. Such attitudes allegedly support cultural differences. However, their underlying assumptions point to fixed and naturalized traits primarily attributed to social groups and confined to a pseudo-psychological culturalism. It concerns society, culture, and the public sphere where discourse and interpretation meet, a space for hermeneutics, a mosaic of dominant and subordinate vocabularies overlapping prejudices, all of which acquire particular saliency in different constellations. ${ }^{10}$

8 Cf. C. Lomnitz-Adler, El antisemitismo y la ideología de la Revolución mexicana (Mexico City: Fondo de Cultura Económica, 2010); idem, Exits from the Labyrinth: Culture and Ideology in the Mexican National Space (Berkeley: University of California Press, 1992); J. Bokser Liwerant, "Sinopia and Pentimenti" (Wistrich Lecture, Jerusalem, 2018).

9 Cf. Lomnitz-Adler, Exits from the Labyrinth.

10 Cf. P.-A. Taguieff, Rising from the Muck: The New Anti-Semitism in Europe (Chicago: Ivan R. Dee, 2004); M. Wieviorka, The Lure of Anti-Semitism: Hatred of Jews in Present-Day France (Leiden: Brill, 2007). 


\section{Antisemitism and Related Prejudices}

Despite the greater conceptual awareness of the complexity of antisemitism, more clarity is still needed to analyze related contemporary expressions of prejudice, exclusion and, specifically, anti-Zionism, in its heterogeneous composition, criticism of Israel and even anti-Israelism. Antisemitism, anti-Zionism, and anti-Israelism are singular yet overlapping phenomena at the meaningmaking level. Latent and manifest dimensions interact.

Criticism of Israel is not necessarily antisemitic in essence or motivation. However, both overlap if prejudiced rhetoric or images drawing on old myths and old/new stereotypes, such as conspiracy theories or the representation of Israel's policies as emblematic of evil, racist, or genocidal states, are used. ${ }^{11}$ By overlapping at the meaning-making level, these phenomena are likely to have significant-and even dangerous-implications. Legitimate criticism of Israel and its policies in light of the long-lasting Israeli-Palestinian conflict is different in its inner and outer sphere of origin, the causality of origin (ethical, universal, cosmopolitan) and the expected outcome (public pressure). A discursive tool may imply a double standard when making judgments regarding Israel's policies toward the Palestinians. Tools may also include the representation of Israel's policies as evil, racist, or genocidal. Such approaches lead to the demonization and de-legitimization of Israel with significant, even dangerous, implications. Antisemitism adopts singular forms that reflect the complex interactions between historic recurrences and changes and between different referents of collective belonging-religion, culture, ethnicity, history, hermeneutics.

Without denying that it is challenging to know the motivations that may drive antisemitism, anti-Zionism, and anti-Israelism, multiple layers of prejudices, cultural configurations, social interests, political constellations, and geostrategic interests can certainly be highlighted. A socio-historical analysis should not focus on intent or motive but its effects, given its societal resonance:

\footnotetext{
Antisemitism should be understood as a social phenomenon that is not reducible to the intent or the self-consciousness of the social actors involved. Antisemitism is a social fact produced through shared meanings and exclusions; it is not an individual moral failing. ${ }^{12}$
}

11 Cf. R. Chazan, Medieval Stereotypes and Modern Antisemitism (Berkeley: University of California Press, 1997).

12 D. Hirsh, "Hostility to Israel and Antisemitism: Toward a Sociological Approach," Journal for the Study of Antisemitism, no. 5 (2013): 1403. 
Inner differentiation also finds expression in its possible outcomes, which include the normalization of hostility toward Israel and (or) Jews; the radicalization of discourse; new thresholds of acceptance, prejudice, rejection and delegitimation of Israel, and symbolic and physical violence. These outcomes become acute in our times characterized by globalization and transnationalization processes leading to new convergences between seemingly different and even opposing actors (a historical feature of modern antisemitism).

Hence the need to approach these singular but overlapping phenomena from a multifactorial perspective.

\section{Singular, yet overlapping}

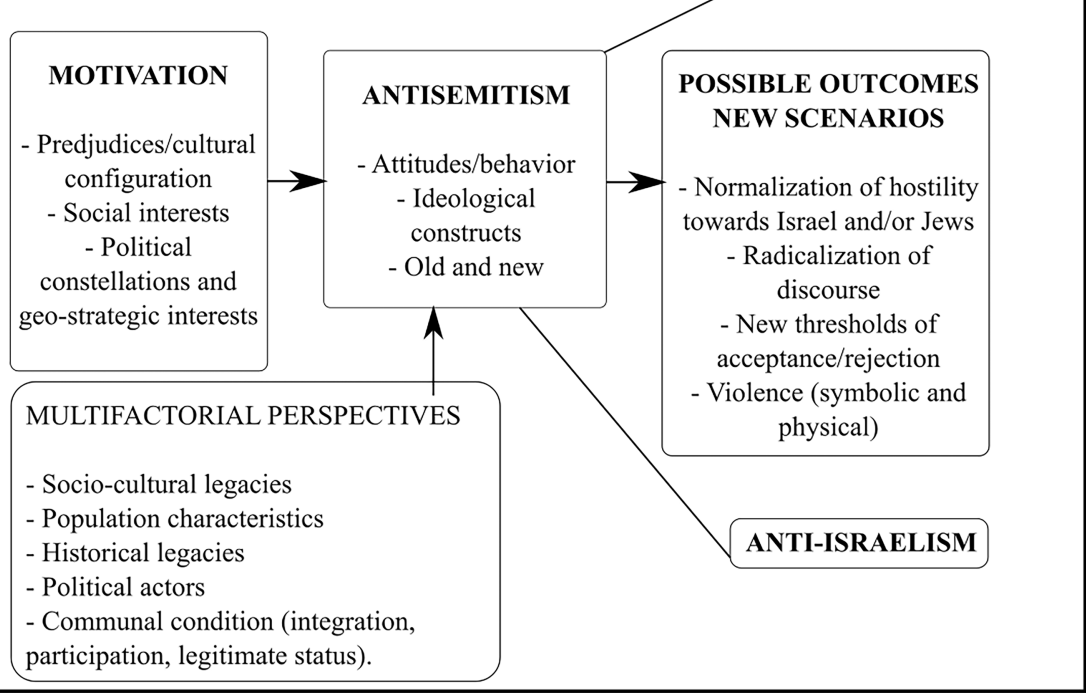

Image 1: Overlapping processes at the meaning-making level.

\section{Conceptual Debates}

The interactions between historical and emerging forms of antisemitism find expression in current conceptual elaborations and prevailing debates that include pragmatic and heuristic dimensions. The discussions have been triggered by the concept of "new antisemitism," around which a broad spectrum of conceptual approaches has been formulated. 
It has been argued that a "new antisemitism" stems from the Left, the Right, and radical Islam, and tends, as a rule, to converge in its opposition to the existence of Israel as a Jewish state. ${ }^{13}$ This new expression is nourished by convergent interests of otherwise opposed political actors that run from the Left to the Right (including nationalists who view Jews as the eternal foreigners) and fundamentalist Muslims who immigrated to Europe carrying their hatred of Israel and the Jews. ${ }^{14}$ It is argued that the new antisemitism of the Left presents several parallel tracks that symbolically converge to include Jews and Israel. Therefore, the terms Jew, Zionist, and Israel are increasingly interchangeable in contemporary discourse globally. ${ }^{15}$

Whereas classical antisemitism involved discrimination against the personhood of Jews, the new one entails discrimination against the statehood of Jews. Thus, both assault the core of Jewish self-definition. This line of thought underscores antisemitism's uniqueness in that classical formulations deny Jews the right to live as equals in society; it now denies Jews the right to live as equals in the family of nations. Some proponents of the concept argue that criticism of Israel and Zionism is most often disproportionate in degree and unique in kind when compared to attitudes toward other foci of conflict worldwide. ${ }^{16}$ The argumentative structure presents several parallel tracks that symbolically converge to include both Jews and Israel.

Other perspectives point to new sources of antisemitism. Pierre-André Taguieff contends that antisemitism is no longer based on racism and nationalism but, paradoxically, on anti-racism and anti-nationalism. It equates Zionism and racism; resorts to Holocaust denial; borrows from the Third-World discourse and the slogans of anti-imperialism, anti-colonialism, anti-Americanism, and anti-globalization, and disseminates the image of the Palestinian as today's unique innocent victim. However, while Jews may not suffer discrimination,

13 Cf. B. Lewis, Semites and Anti-Semites: An Inquiry into Conflict and Prejudice (New York: Norton, 1999); Taguieff, Rising from the Muck.

14 Cf. J. R. Fischel, “The New Anti-Semitism," Virginia Quarterly Review 81, no. 3 (2005): $225-34$.

15 Cf. B. Cohen, "The Persistence of Anti-Semitism on the British Left," Jewish Political Studies Review 16, nos. $3 / 4$ (2004): 157-69; S. Edelman, "Antisemitism and the New/Old Left," in Not Your Father's Antisemitism: Hatred of the Jews in the Twenty-First Century, ed. M. Berenbaum (St. Paul: Paragon House, 2008), 271-94; D. J. Goldhagen, The Devil That Never Dies: The Rise and Threat of Global Antisemitism (New York: Little, Brown, 2016).

16 Cf. I. Cotler, "Human Rights and the New Anti-Jewishness: Sounding the Alarm" (Jerusalem: The Jewish People Policy Planning Institute, 2002); L. N. Powell, Troubled Memory: Anne Levy, the Holocaust, and David Duke's Louisiana (Chapel Hill: University of North Carolina Press, 2002). 
they are often victims of stigma, threats, physical violence, and narratives that build on the negative tropos, which endorse radical anti-Zionism. Judeophobia or neo-judeophobia expresses itself in violence incited by radical Islamists. It becomes a cultural given on a public scene mechanically and unanimously supportive of a counter-cause that transcends the boundaries between Left and extreme Left. Its anti-Israelism, coupled with anti-Americanism, permeates all parts of right-wing opinion. Judeophobia accuses the Jews of being "too community," too religious and nationalistic, as well as too cosmopolitan. Zionism as victimizer is the ideological core mode of legitimation for contemporary anti-Jewish violence. This awakens old accusations of "ritual murder," that is, the blood libel. ${ }^{17}$

Michel Wieviorka emphasizes the multiple sources of antisemitism: far-right and far-left circles, given milieus in the Muslim population, youngsters of disadvantaged educational contexts or the spin-offs of the Middle East conflict and the sympathy awakened by the Palestinian cause among educated strata. Nevertheless, Wieviorka views antisemitism as one aspect among many of general societal malaise and not a major crisis in its own right. ${ }^{18}$

Scholars such as David Hirsh take a different stance by asking if Israel's criticism is necessarily antisemitic. In his view, the problematic argument for some "critics of Israel" to deal with is that criticism is often expressed by using rhetoric or images that resonate as antisemitism: holding Israel to higher standards than other states, articulating conspiracy theories, using demonizing analogies and harmful stereotypes, casting Jews in the role of oppressors, formulating criticism in such a way as to aggravate the vast majority of Jews and any other instance of using the word "criticism" but meaning discriminatory practices against Israelis or Jews.

As mentioned above, Hirsh adds that the recurrence of antisemitism does not mean witnessing a repetition of the same phenomenon, but one that may bring old elements while acquiring new expressions, responding to different logics and framed by distinct individuals and groups. One problem with the "Hydra" explanation is that while each form of anti-Judaism draws on and replicates older forms, "they are also hugely different phenomena. They arise, and they become widespread in radically different times and places. They have different manifestations and are employed by different social forces; they use different narratives.”19 Such differences are as striking as the commonalities between

17 Cf. Taguieff, Rising from the Muck; idem, La nueva judeofobia: Israel y los judios, desinformación y antisemitismo (Barcelona: Gedisa, 2009).

18 Cf. Wieviorka, The Lure of Anti-Semitism.

19 Hirsh, “Anti-Zionism and Antisemitism," 20-21. 
the Spanish Inquisition, Christian antisemitism in nineteenth-century Poland, socialist antisemitism in Germany at the time of August Bebel, right-wing antiBolshevism, Nazi racist and genocidal antisemitism, understated and gentlemanly English exclusion, contemporary anti-imperialist anti-Zionism and Jihadi antisemitism. Anti-Zionism is indeed defined as antisemitism because it denies Jews' right to self-determination while defending self-determination for all other nations. ${ }^{20}$ Its structural argumentative continuity takes place through historical elaborations.

In his extensive analysis of antisemitism and the perception Jews have of it, DellaPergola ${ }^{21}$ analyzes the relationship between three principal axes: the recurrent historical and analogical demonizing strategy; the emphasis on permanent alterity, foreignness, detachment, and the questioning and denial of the Holocaust. He analyzes how Israel and the Holocaust are prevalent lines that point to the winds of time and emerge through their close links and association.

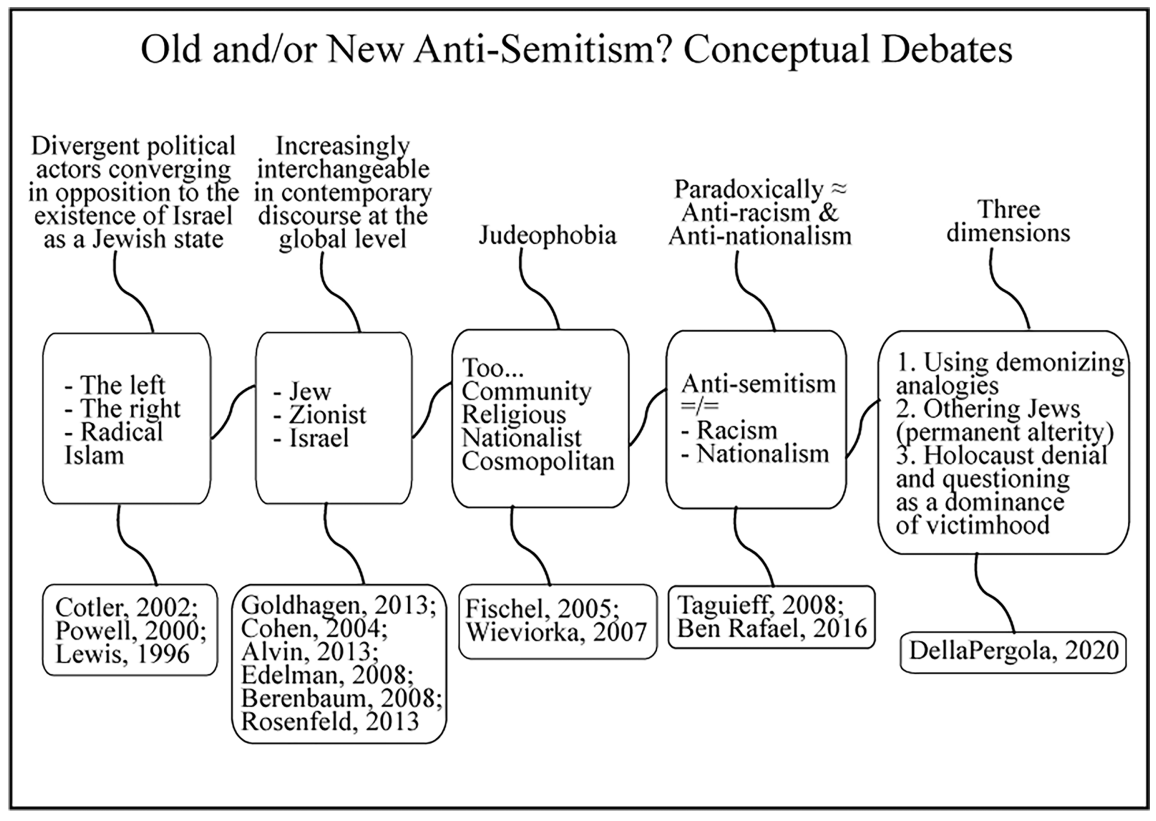

Image 2: Old and/or new antisemitism? Conceptual debates.

20 Cf. D. Matas, Aftershock: Anti-Zionism and Anti-Semitism (Toronto: Dundurn, 2005).

21 Cf. DellaPergola, "Jewish Perceptions of Antisemitism in the European Union, 2018." 
Contrasting approaches downplay the significance of the new antisemitism. Much of the recent discourse on it is deemed to blur conceptual differences between antisemitism, criticism against US imperialism, and condemnation of both

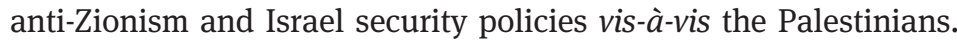

Brian Klug considers that the new prejudice is not strictly speaking antisemitism but rather a recent phenomenon. ${ }^{22}$ He argues that the concept is unhelpful because it devalues the historical significance of the term, transforming it into a part of a mindset, a way to overstate criticism and hostility of the Left toward Israel as irredeemably antisemitic prejudice. Earl Raab argues that charges of antisemitism based on anti-Israel views usually lack credibility. Thus, people supporting the Palestinians resent being wrongly accused of antisemitism, and the Jewish state's supporters exploit this alleged stigma to silence legitimate criticism of Israel's policy. He further states that accusations of antisemitism based on anti-Israel opinions lack credibility and that reasonably informed people think that Israel has the largest share of responsibility for the IsraeliPalestinian conflict. ${ }^{23}$

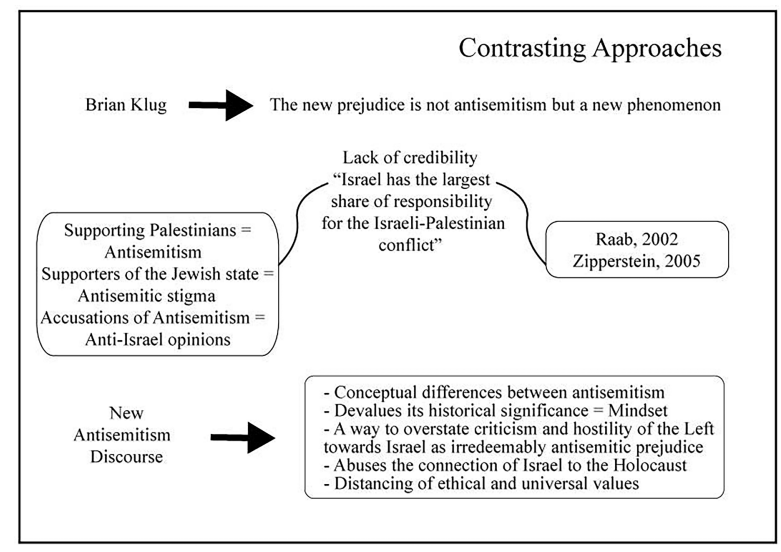

Image 3: Contrasting approaches.

22 Cf. B. Klug, "The Collective Jew: Israel and the New Antisemitism," Patterns of Prejudice 37, no. 2 (2003): 117-38; idem, "Is Europe a Lost Cause? The European Debate on Antisemitism and the Middle East Conflict," Patterns of Prejudice 39, no. 1 (2005): 46-59.

23 Cf. E. Raab, “Antisemitism, Anti-Israelism, Anti-Americanism,” Judaism 51, no. 4 (2002): 387-96; S. J. Zipperstein, "Historical Reflections on Contemporary Antisemitism," in Contemporary Antisemitism: Canada and the World, ed. M. R. Marrus, D. J. Penslar, and J. Gross Stein (Toronto: University of Toronto Press, 2005), 52-63. 
Amidst the ongoing debates on antisemitism and new antisemitism, post-colonial and de-colonial perspectives gained ground in the framework of the Global South's conceptual and political formulations, where Latin America stands as itself and a symbol of other exclusions. Indeed, confronting the Global North, the Global South is conceived as the space of liberation from Western political, social, and epistemological assumptions that justify domination, economic takeover, and cultural management. Its focus is on the matrix of the colonial link between knowledge and power, allegedly diluted and obscured under modernity's Western epistemology. The argumentative rationale is based on the limits of the "unseen history"-the history of coloniality hidden under or behind Modernity's history, for example, the history of the second nomos. ${ }^{24}$ The Global South thus becomes a conceptual and geopolitical territory that recovers conceptual exploration of the experience of the expansion of the West and the foundation of a hegemonic World System that defined its periphery. ${ }^{25}$

The decolonial debates approach a radical critique of Zionism, Israel, and the Jews overlapping prejudices in explicit or implicit transferring of meanings.

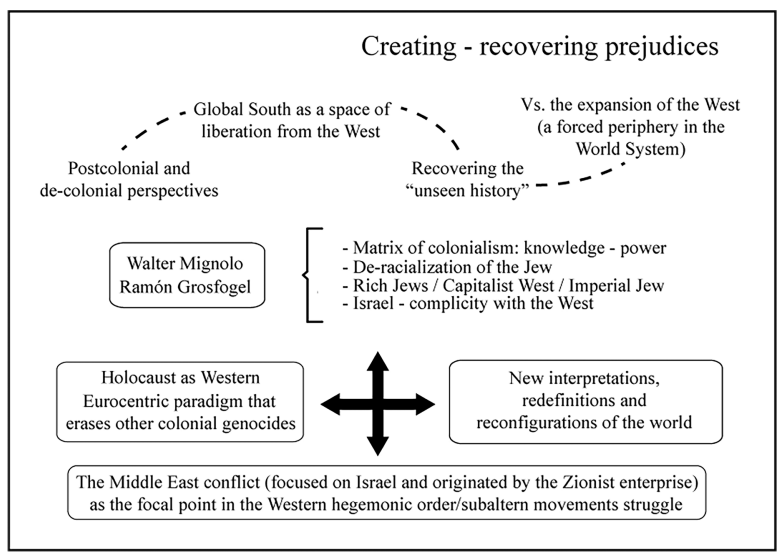

Image 4: Creating-recovering prejudices.

24 Cf. W. D. Mignolo, “The Global South and World Dis/Order," Journal of Anthropological Research 67, no. 2 (2011): $165-88$.

25 Cf. A. Quijano and I. Wallerstein, "La americanidad como concepto, o América en el moderno sistema mundial," Revista Internacional de Ciencias Sociales 134, no. 4 (1992): 583-91. 
In contrast to Islamophobia, which is framed as a Western ideology against non-Western subalterns, antisemitism is conceived as an outcome of the Israeli state's imperialist and colonialist establishment.

Indeed, one core element of the decolonial conceptions regarding the relations between antisemitism and racism finds its source in the whitening of the Jewish collectives compared to other racialized groups. As analyzed by Julia Edthofer, one of the central problematics lies in

[the] dismissal of the very functionality of antisemitic racialization ultimately relates to one core element of de-colonial misconceptions regarding the relation of antisemitism and racism(s)-namely to the discursive "whitening" of Jewish collectivities when compared with other racialized groups. ${ }^{26}$

Thus, it implies both the negation of the antisemitic racialization of the Jew and the recovery of other racialized collectives. Mignolo further brings the Zionist project and Israel's state under the optic of Israel's collaboration with Western Imperialism. He would ultimately explain antisemitism and anti-Zionism as reactive: they are a consequence of the cooperation between Western neo-liberalism, capitalism, and secular Jews. For that, an old-new stereotype-essential to the negative tropos-is the rich and established Jews collaborating with the capitalist and colonial world order.

Focused on Israel, the Middle East conflict-originated by the Zionist enterprise-becomes the focal point of the global conflict between the Western neocolonial world order and the subaltern resistance of the rest. ${ }^{27}$ Gradually an exercise in conceptual synonymy nourishes the public narrative and is in turn nourished by it-Israel becomes a genocidal state; Israel is carrying out Nazilike atrocities; Gaza is equivalent to the Warsaw Ghetto; Israel was born as a settler colonial state. ${ }^{28}$

The other line of thought embedded in the post-colonial perspective refers to another of the pillars of current antisemitic arguments: the Shoah. The Holocaust

26 J. Edthofer, "Israel as Neo-Colonial Signifier? Challenging De-Colonial Anti-Zionism,” Journal for the Study of Antisemitism 7, no. 2 (2015): 39.

27 Cf. R. Grosfoguel, "Human Rights and Anti-Semitism After Gaza," Universitas Humanística, no. 68 (2009): 157-77.

28 Cf. Grosfoguel, "Human Rights and Anti-Semitism after Gaza"; D. Lloyd, "Settler Colonialism and the State of Exception: The Example of Palestine/Israel," Settler Colonial Studies 2, no. 1 (2012): 59-80; R. Busbridge, “Israel-Palestine and the Settler Colonial 'Turn’: From Interpretation to Decolonization,” Theory, Culture \& Society 35, no. 1 (2018): 91-115; L. Veracini, "The Other Shift: Settler Colonialism, Israel, and the Occupation," Journal of Palestine Studies 42, no. 2 (2013): $26-42$. 
is criticized as a Western Eurocentric remembrance paradigm stressing the alleged role Europe has assigned to the remembrance of the Holocaust as a unifying remembrance, omitting and erasing other past colonial genocides.

\section{Snapshots of Tropos-Building: Historical Perspective on Latin America}

The cumulative character of the negative tropos of the Jew and its different referents-from the individual to the collective; from the ethnic to the national; from diasporic existence to state existence-has interacted with changing historical circumstances. Continuity and change have been part of representations and praxis. Otherness, alterity, and its negative perception were part of a dynamic of acceptance and rejection.

For Latin America, Jewish Otherness was embedded in visions and immigration and exile policy. Antisemitism's impact on the social representation of the Jew as the Other was built with the arrival of Jewish immigration during the 1920s-1940s. Throughout these decades, migration became a prominent sphere in which different concepts of the nation and the desired type of society were formulated, and around which antisemitic expressions were articulated. Indeed, antisemitic stereotypes, prejudices, and behavior that were projected into norms and practices substantially impacted immigration policies. The official criteria that regulated the influx of Jewish immigration, first, and the Jewish exile, later-both for economic and ethnic-racial reasons-were widespread among the pressures of different social sectors and antisemitic associations that aimed to curb Jewish entrance to countries, which makes the analysis of concurrent social processes and political factors more complex.

During this period, antisemitism developed in the context of fundamental national political trends and was part of the rise and consolidation of European Nazism. Otherness was socially represented as foreignness amid debates that resulted in restrictive policies toward Jewish immigration and Jewish refugees and became a prominent sphere in which different antisemitic expressions were articulated.

In light of the challenges faced during these decades, complex interactions between widespread anti-Jewish prejudices and governmental policies developed. Nationalism bifurcated; the different modes of interpretation of the national interest were gradually polarized. The Right acquired growing strength, articulating prejudices that originated in Europe and were adapted, recreated and nourished by each country's reality. In different political and cultural constella- 
tions, the main referents of the negative tropos were brought together, combined, and overlapped.

These decades were also marked by interconnected national, regional, global histories, and separate ones. Interconnected phenomena coexisted with social and political efforts by societies and governments to disassociate from the critical issue of Jews needing to abandon Europe. The international fora that addressed the refugee crisis during Nazism are exemplary cases. At both the Evian Conference (France, July 1938) and the first meeting of the Intergovernmental Committee on Refugees (London, August 1938), the Latin American nations were influenced by each other's positions as well as by pressure from the great powers and thus acted as a regional bloc, rather than making decisions solely on the basis of local or national considerations. ${ }^{29}$

Debates in these arenas expressed, transmitted, and reinforced prejudices that informed the negative images of the Jew, shaped national attitudes, yielding arguments that strengthened ambivalence, fostered indecision toward the refugee problem, and ultimately led to policies of exclusion. Renewed arguments were displayed that emphasized the Jewish community's separateness and its differences from the general population or the notion that Jews brought inconveniences and risks to the country.

In the case of Mexico, one of the paradoxes that must be highlighted is that despite the conceptual, ideological, and political differences that motivated right-wing groups and the economic and ethno-historic motivations that fueled official immigration policies, from the point of view of restricting Jewish immigration, there actually were meaningful interactions and convergences. Pragmatism and ideology interacted, stereotypes too.

The convergences can be seen in the argumentative structure of the extremeright antisemitic organization Acción Revolucionaria Mexicanista, other antisemitic organizations that spread, right-wing intellectuals, and the socialist government of Lázaro Cárdenas. The recurrence of historical prejudiced expressions and the appearance of new ones can be discerned in the following graphic.

Indeed, the entry of Jews as immigrants and refugees was limited by and subjected to a restrictive logic. Concerning the refugees, restrictive policies prevailed in most Western countries. It defined a world pattern characterized by the continuity of the restrictive measures on immigration adopted since the

29 Cf. J. Bokser Liwerant, "El México de los años treinta: cardenismo, inmigración judía y antisemitismo," in Xenofobia y xenofilia en la historia de México, siglos XIX y XX: Homenaje a Moisés González Navarro, ed. M. González Navarro and D. Salazar Anaya (México: SEGOB, Instituto Nacional de Migración, Centro de Estudios Migratorios; Instituto Nacional de Antropología e Historia; DGE Ediciones SA de CV, 2006), 379-415. 


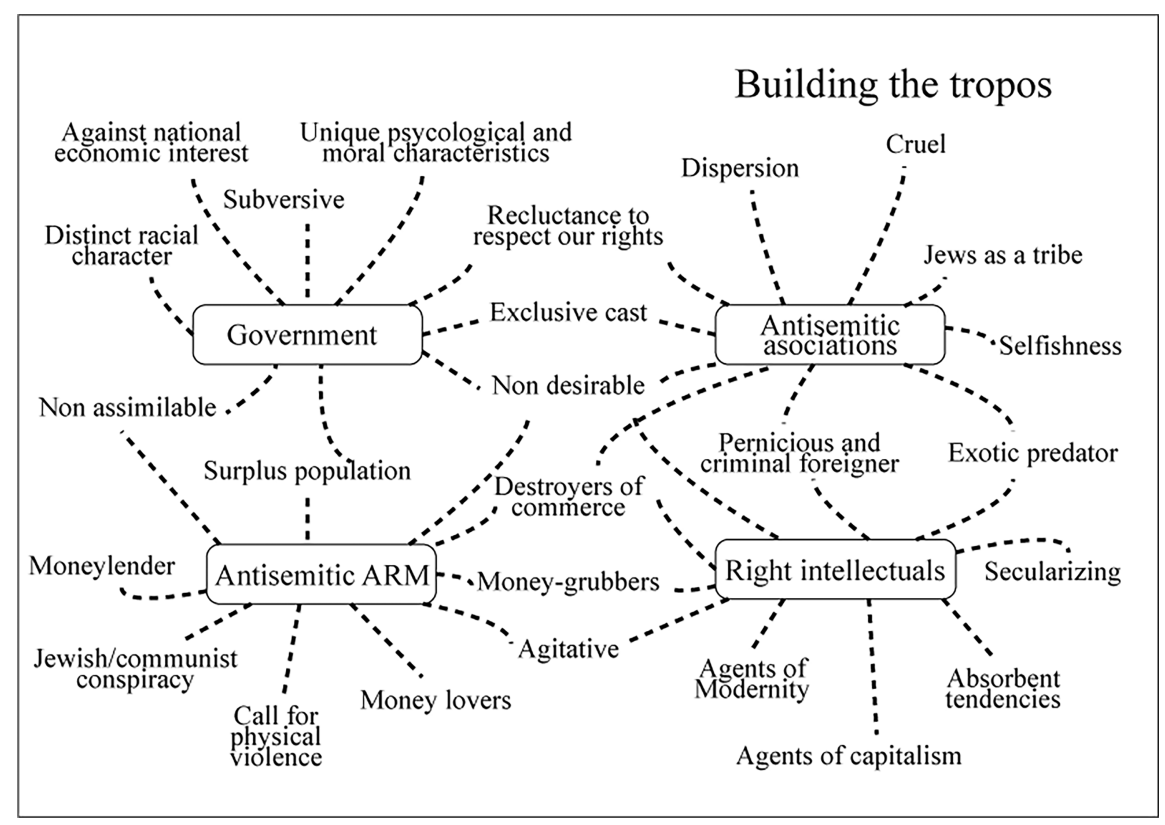

Image 5: Converging different and antagonistic sources of anti-Jewish prejudice. The Mexican case.

early 1930s and the limitations set on refugee admittance as Nazism took hold. However, in the Mexican case, this pattern contrasted with the country's open attitude concerning other exiles, notably Spaniards. Without ignoring the impact of several elements and factors in defining a restrictive immigration policy, the perception of Otherness vis-à-vis Jews as an obstacle to their admission, the stereotypes engendering prejudices that Nazism brought to the forefront enhanced it. $^{30}$

Other countries restricted Jewish immigration with criteria similar to those of Mexico. The Colombian Ministry of Foreign Affairs limited the entry of German Jews in 1938, and restrictive measures had already been applied to Jews from Romania, Poland, and Russia since 1930. It based its decision on the assessment that Jews represented a severe problem for Colombian integrity due to being "a ubiquitous, diffuse people, bearing the mark of every nationality and-strictly

30 Cf. Bokser Liwerant, "El México de los años treinta”; idem, "Identidades colectivas y esfera pública: judíos y libaneses en México,” in Árabes y judíos en Iberoamérica similitudes, diferencias y tensiones, ed. R. Rein (Mexico City: Fundación Tres Culturas, 2008), 323-58. 
speaking-none at all." This condition of statelessness was added to "their formidable capacity for adaptation and mimicry that allows them to conform to the most extreme, diverse circumstances, their wandering condition that is so favorable for commerce and making a profit."31

Costa Rica witnessed intense antisemitic campaigns between the 1930s and the 1950s, encouraged by tradespeople, the middle classes, and the Nazi Party. Perhaps the ultimate leader of these campaigns was politician Otilio Ulate, who was president between 1949 and 1953. Ulate owned the newspaper El Diario de Costa Rica. He published all sorts of antisemitic propaganda, accusing Jews of ruining national commerce, spreading communist ideas, practicing a satanic religion, and even degrading the milk they sold to children. Jews suffered various acts of violence during these campaigns: attacks on their businesses, antisemitic graffiti on their homes, arbitrary detentions, and being forced to show their belongings under suspicion of carrying communist propaganda. The synagogue in the capital, San José, was also set on fire in April 1948. The antisemitic attacks lasted well into the Cold War, headed by the extreme right-wing organization Movimiento Costa Rica Libre (MCRL), which saw Jews as the agents responsible for spreading communism.

The alternative ways in which prejudices that conform to the anti-Jewish tropos were used can be seen in the Brazilian case. Images of Jews began to change in Brazil in the 1930s, linked to how Brazilian antisemitic stereotypes were conceived and discussed. By maintaining traditional ones and modifying the meaning that accrued to them, international relief organizations could turn accepted stereotypes to refugees' advantage. Thus, the image of Jews, which involved their financial and economic success could be glorified for their ability to help domestic industrial development by injecting capital into Brazil, instead of being denounced as part of an international conspiracy to force national wealth out of the country. ${ }^{32}$

Different types of nationalism that developed and expanded during the following decades found roots in the continent, further nourishing a strong harmful tropos component and found expression in acts of symbolic and physical violence. Indeed, a series of actors turned violence into one of their central axes of political action and shaped an extreme version of nationalistic antisemitism.

Around the conceptualization of fascism, of peripheral fascism, and its populist regional version, the revision of its alleged inclusionary vision was con-

31 Ministerio de Relaciones Exteriores, Memoria del Ministerio de Relaciones Exteriores presentada al Congreso Nacional (Imprenta Nacional, 1938), viii.

32 Cf. J. Lesser, Welcoming the Undesirables: Brazil and the Jewish Question (Berkeley: University of California Press, 1995). 
fronted with its exclusionary dimensions, as specifically has been the case of Argentina's sustained antisemitism throughout the twentieth century. ${ }^{33}$ It built on the nationalist organizations of the 1930s that formulated rhetorical principles aimed at popularizing nationalism like violence, anti-imperialism, and social justice. ${ }^{34}$

Antisemitism was one of the pillars of the right-wing Argentine nationalist imaginary, which directed discourses and practices as a mobilizing myth that strengthened its own identity by opposing it to the negative identification of Jewish Otherness as the mortal enemy of the nation. As a social field with heterogeneous actors, nationalists developed a differentiating habitus about different ways to approach the "Jewish problem" and possible solutions in their antisemitic discourse, all linked by the generalized condemnation of Jewish presence in Argentina.

Exemplary is the historical context of the antisemitic organization Tacuara, a period of approximately ten years between President Juan Domingo Perón's overthrow in 1955 and General Juan Carlos Onganía's rise to power in 1966. Holocaust denial is represented as the revelation of one more Jewish fabrication aimed at stigmatizing Nazism (a truly nationalistic movement) and presenting themselves as victims to achieve one of their old conspiratorial goals: establishing a home for the descendants of David in Palestine through the creation of Israel. The victim then becomes a sinister victimizer who delegitimizes his adversary to fulfill his dark plan. Although Jews had been seen as foreign agents incapable of assimilation since the 1930s, in the 1960s, because of the Eichmann event, nationalist antisemitism began underlying anti-Zionism to justify their rejection of Jews based on the argument that their foreignness made them subservient exclusively to Israel's interests, as harmful to the country as Anglo-Saxon imperialisms and the communist shadow of Moscow.

From there, accusations of "dual loyalties" rained down on Argentinian Jews: a conspiratorial plot by Israel, their true motherland, destined to promote their growth to the detriment of their host country, making them obey their new Land of Zion and not the Argentinian state, which made them the internal enemies of the latter.

33 Cf. M. García Sebastiani, ed., Fascismo y antifascismo, Peronismo y antiperonismo: Conflictos políticos e ideológicos en la Argentina (1930-1955) (Madrid/Frankfurt am Main: Vervuert, 2006); F. Finchelstein, La Argentina fascista: Los orígenes ideológicos de la dictadura (Buenos Aires: Editorial Sudamericana, 2008).

34 Cf. S. M. Deutsch, Counterrevolution in Argentina, 1900-1932: The Argentine Patriotic League (Lincoln: University of Nebraska Press, 1986). 
For Leonardo Senkman, these accusations tried to legitimize the antisemitic, xenophobic ideology that, this time, required anti-Zionism as a doctrinal need to explain the conspiracy theory as a method for interpreting history, stalked by a mythical, many-headed synarchy. ${ }^{35}$ The renewal of Argentinian antisemitism's tradition and its transit into anti-Zionism was not exclusive to the far Right: the historical foundations of political instability in Argentina made outbursts of antisemitism possible even under democratic regimes. Overlapping of arguments, negative stereotypes, and prejudices, as the elaboration of new equations took place, can be seen in the following image:

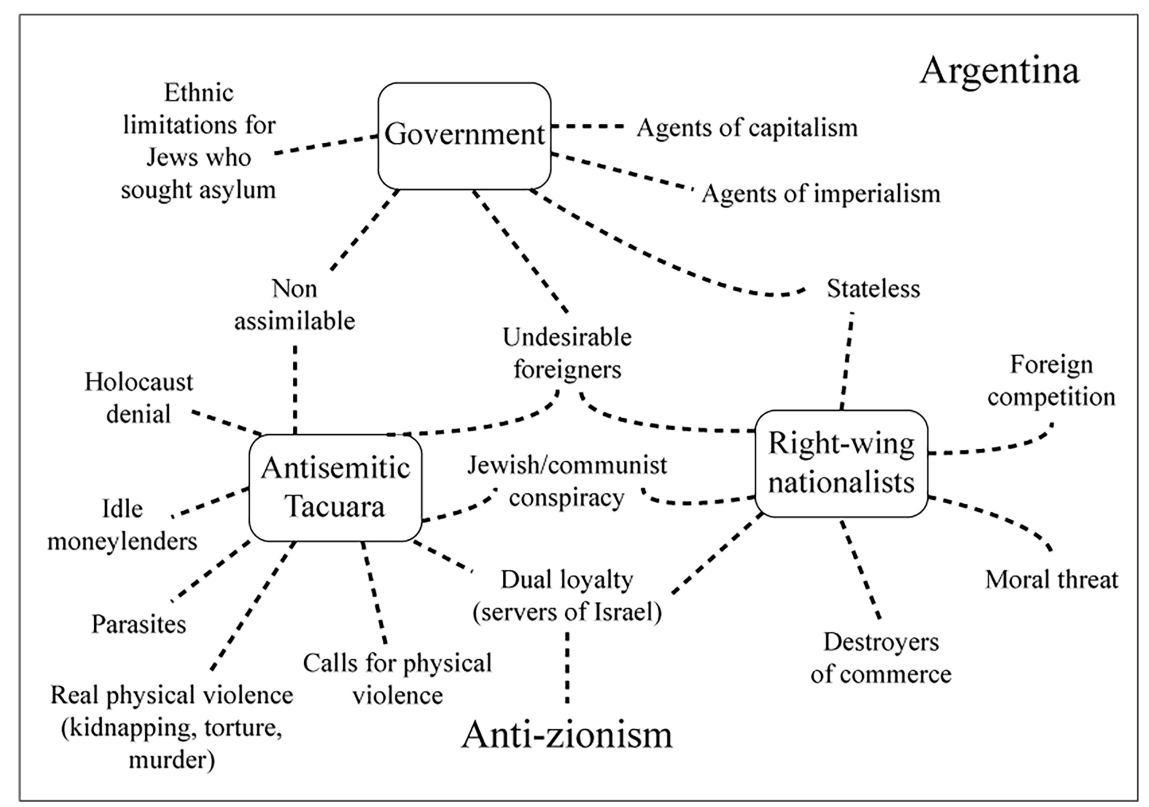

Image 6: Tropos-building in Argentina: Advancing the anti-Zionist paradigm.

35 Cf. L. Senkman, El antisemitismo en la Argentina (Buenos Aires: Centro Editor de América Latina, 1986). 


\section{Critical Juncture: Zionism, Racism, Regionalization-Ideological Elaborations and the Expansion of a tropos}

Representations of mythical prejudices continued to develop in changing political constellations. Indeed, during the 1970s, as an aftermath of the Six-Day War, the national, regional, and global scenarios were reconfigured, and antisemitic expressions gradually catalyzed through political codes that would bring together the triangle: Jews, Israel, and Zionism. This process reached its climax with UN Resolution 3379, which equated Zionism with racism, thereby entering the international dynamics while projecting entrenched stereotypes onto the State of Israel and the Jewish people.

Anti-Zionism recovered old antisemitic referents, combining the hard nucleus of prejudice with changing motivations and functions. Symbolic violence calls for hatred and enables discrimination intertwined with (the old) referents of ascription. Mexico will again provide a case study. The Jew representation transited from being the only Other to the redefinition of Otherness in new terms; it may be considered paradigmatic of the confluence of transnational trends, regional and national contextual settings. ${ }^{36}$

Mexico's positive vote was interpreted as an expression of the progressive stance of the government, whose domestic policies aimed to incorporate dissent and opposition, mainly in the intellectual sectors. Moreover, the meaning that Mexico's vote acquired in the domestic realm linked the condemnation of Zionism with the promotion of democratization. Global and regional perspectives also reinforced the relationship between progressive stands and anti-Zionism. Mexico was the World Conference setting for the International Women's Year, a significant precedent of Resolution 3379 that already incorporated Zionism's condemnation in the fight against colonialism, equating Zionism with apartheid and other forms of racial discrimination. Such perspectives intertwined with an ideology and a discourse that brought the Third World as an actor. The drafting of the Charter of Economic Rights and Duties of States, the goal of establishing an Economic System for the Third World, together with the proposal to increase its participation in international organizations, constitute some of the emblematic moments of President Luis Echeverría's project. It would encompass a collec-

36 Cf. J. Bokser Liwerant, “Fuentes de legitimación de la presencia judía en México: el voto positivo de México a la ecuación sionismo-racismo," in Judaica Latinoamericana III, ed. M. Bejarano and E. Zadoff (Jerusalem: Hebrew University of Jerusalem; AMILAT, 1997), 319-50. 
tive bargaining power and the examination of specific programs of economic, financial, industrial, and technological cooperation.

Following Mexico's vote against Zionism, US Secretary of State Henry Kissinger declared that his government would retaliate against those countries that voted in favor of the resolution, even before it would take any action against the UN. In this context, the Jewish community in the US announced its decision to cancel tourist trips to Mexico. Its justification was that "Americans make more business and touristic trips to Mexico than to any of the other 71 nations that voted against Zionism.” The interplay between discourse and practice developed in complex ways, given that the Mexican regime attempted to "rectify the vote" through arguments intersecting different moments: the vote against Zionism, the tourism boycott declared by the US, and the attempt to amend Mexico's position at the UN. "Rectifying measures" that aimed to clarify the "misunderstandings" associated with the vote included the visits of high-level politicians to Chicago, Los Angeles, and New York, where meetings with Jewish leaders were held, as well as the foreign minister's trip to Israel. ${ }^{37}$ Foreign Minister Emilio Rabasa asserted on several occasions that Zionism was not racism, that there was no discrimination in Israel-exemplified by a floral offering at Herzl's grave-and that given the clarifications of the matter, the "misunderstanding was forgiven and forgotten." ${ }^{38}$

However, despite that the official discourse sought to differentiate between the condemnation of Zionism and antisemitism, ${ }^{39}$ critiques of Zionism also included anti-Jewish prejudice in particularly acute ways. Thus, Zionism was seen not only as expansionist and colonialist, ${ }^{40}$ but also as a "doctrine based on ethnic motivations, relentless, messianic, discriminatory and even brutal," or as the "combination of a religious fanaticism and an exclusionary nationalism, both equally racist." It was further defined as an ideology "that reflected

37 Cf. “Antisionismo no es antisemitismo,” El Universal, December 11, 1975; "Los malos entendidos,” El Universal, December 6, 1975.

38 “'Completa tolerancia religiosa hay en Israel,' afirma Rabasa,” El Nacional, December 8, 1975; El Nacional, "Ofrenda de Rabasa ante la tumba del 'padre del sionismo'," December 6, 1975; Excelsior, “Llegó Rabasa a Tel Aviv, 'para discutir cualquier malentendido', dijo,” December $5,1975$.

39 Cf. J. L. Huerta Cruz, "Antisionismo no es antisemitismo,” El Universal, November 27, 1975. 40 Cf. G. González, “Amenazas Norteamericanas. Falta de bases históricas y legales,” Excelsior, November 17, 1975; idem, "Diplomacia caprichosa: ¿hay algo que perdonar?,” Excelsior, December 15, 1975; A. Lara Barragán, "El judaísmo internacional," El Universal, December 6, 1975. 41 J. M. Téllez Girón, “Judaísmo, sí; sionismo, no,” El Día, December 1975; T. G. Allaz, "Estatuto de animales para los no judíos,” Excelsior, December 1975; T. G. Allaz, "Israel, víctima de sí Mismo,” Excelsior, December 1975. 
the belief of God's chosen people; as if Jews segregate, have pride and believe to be superior to other races." 42

It also reinforced the symbolic connection between Jewish pressure, AKA the Jewish lobby, and loss of autonomy. The radicalized prejudice emerged: that the boycott confirmed its racist and imperialist attitude. ${ }^{43}$ The argument that Jews were an influential and alien group reappeared in the Mexican context.

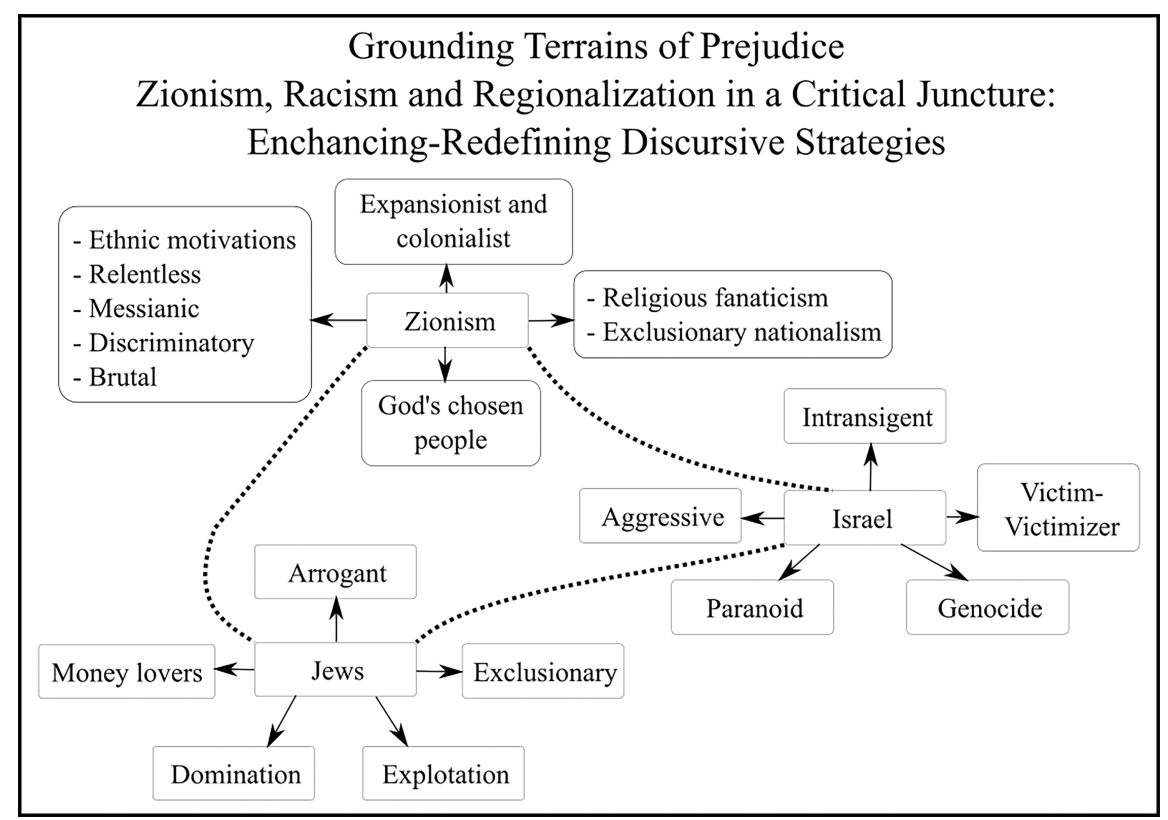

Image 7: Grounding terrains of prejudice.

The radical questioning of the whole paradigm stood at the intersection of ideological discourse, social representations, and political conflicts. Mexico

42 E. Ilanes, "Elitismo pero no racismo," Novedades, November 22, 1975; J. L. Huerta Cruz, "No sólo discriminación semántica del racismo,” El Universal, December 29, 1975; S. Chávez Hayhoe, “Sionismo y racismo," El Universal, November 27, 1975; A. Armendáriz, “¿Semitismo o sionismo?,” Novedades, December 1, 1975; L. Zea, “¿Qué es por fin el sionismo?,” Novedades, December 16, 1975; idem, "El sionismo y las trampas del pacifismo," Novedades, December 23, 1975. 43 Cf. Zea, "El sionismo y las trampas del pacifismo”; idem, “¿Qué es por fin el sionismo?”; A. Villegas, "Balance político de 1975. Candidato, grupos de presión, Israel,” Excelsior, December 22, 1975. 
and the continental scenario were paradigmatic of what Shulamit Volkov has defined as cultural code. This means that antisemitism becomes a sign of cultural identity, of one's belonging to a specific cultural camp. She uses this concept for the study of Imperial Germany "Contemporaries, living and acting in Imperial Germany, learned to decode the message. It became a part of their language, a familiar and convenient symbol." ${ }^{44}$ However, anti-Zionism, and also antisemitism, became part of a larger, more comprehensive ideological "package deal," which had components of anti-colonialism and anti-capitalism. Volkov notes that in the late 1960s and the 1970s, expressions of anti-Israelism and antiZionism were frequently presented by leaders of developing countries as declarations of solidarity with the Arab cause. At this point, she says, the anticolonial struggle came to be based on its cultural contours. Concomitantly, it turned into an attack on cultural conceit, on disregard for the suffering of non-white peoples, on the traditional paternalism and cultural arrogance of the colonizers. As Volkov suggests, it was an assault on the values of the imperialist West, its priorities, excesses and vices, of which, in this context, the Jews became a symbol: "by attacking them one was finally up in arms against all and every manifestation of Western culture." She adds that "cultural as well as social and political views come in packages, in the form of ideational syndromes" and that "only relatively minor issues, though of the kind that are common enough in public discourse, can serve as codes, signifying larger, more important syndromes." 45

In Latin America, Jews and Israel became associated with the US in this cultural code. As in Imperial Germany, where Volkov identified two notorious cultural camps, in Latin American countries, we can also find at least two different cultural camps: the one that associates US and Israel with freedom, democracy and progress, and the other that identifies them with cultural and economic imperialism and colonialism and with the use of military force to achieve those aims. $^{46}$

44 S. Volkov, “Antisemitism as a Cultural Code: Reflections on the History and Historiography of Antisemitism in Imperial Germany," The Leo Baeck Institute Yearbook 23, no. 1 (1978): 25-46. 45 S. Volkov, "Readjusting Cultural Codes: Reflections on Anti-Semitism and Anti-Zionism," Journal of Israeli History 25, no. 1 (2006): 51-62.

46 Cf. L. Senkman, "Anti-Zionist Discourse of the Left in Latin America: An Assessment," in Reconsidering Israel-Diaspora Relations, ed. E. Ben-Rafael, J. Bokser Liwerant, and Y. Gorny (Leiden: Brill, 2014), 309-33; J. Bokser Liwerant and Y. Siman, "Antisemitism in Mexico and Latin America: Recurrences and Changes," in Antisemitism in North America: New World, Old Hate, ed. S. K. Baum et al. (Leiden: Brill, 2016), 21-173. 
The permanent and problematic relationship between ideological discourse and symbolic representations, on the one hand, and political conflicts, on the other, and how symbolic violence can not only shape a conflict but transpose it, contributing to its configuration even if its root causes have changed, were expressed in a paradigmatic way during the Gulf War. Fueled by fifteen years of international reinforcement and mediated by the invasion of Lebanon and the events of Sabra and Shatila, the initial anti-Zionist discourse was projected as a total delegitimization of the Zionist paradigm. In that discourse encouraged by the conflict, more primitive antisemitic stereotypes appeared as well. Thus, Jews were portrayed as arrogant, exclusionary money-lovers of questionable morality. They were also seen as someone who cannot exercise a "nonprejudiced and autonomous thought." ${ }^{47}$ Given that Israel was seen as a military power that was "paranoid by nature and set as its main objective the displacement, and even ... the destruction of ... the Arab race," it was asserted that "dispossession was followed by expansionism and genocide." 48

The victim-perpetrator dialectic was inverted, thus projecting the Nazi Holocaust onto relations with the Palestinians, arguing that the Jewish people "[have] always raised the suffering of the diaspora and the Holocaust around the world." However, Israel was the perpetrator of a new Holocaust as they (Jews, Israelis) had "learned from their own Nazi killers, the use of violence to impose their interests." ${ }^{49}$ This evil inversion was also expressed in the questioning of Israel as an entity that was "doing to the Palestinians what Hitler did to the Jews," 50 "playing the eternal role of the attacked victim given that it has benefited from it over time," 51 and succeeding given their economic power in turning the Holocaust "into the massive crime more widely publicized in the history of humanity" in contrast to the Palestinians who lack the means to broadcast their own genocide. ${ }^{52}$

47 R. García Jaime, “El judío,” Uno más uno, February 4, 1991.

48 H. Bellinghausen, “¿Razas arrasadas?,” La Jornada, January 24, 1991; “Duro golpe a la OLP, la muerte de Abu Iyad; era considerado un héroe por los palestinos,” La Jornada, January 16, 1991.

49 "Autorizan al ejército israelí disparar contra palestinos que arrojen piedras," El Día, December 12, 1990; E. Segovia, "Palabras de México en la filosofía y en la ONU," El Día, February 27, 1991; L. Zea, "Israel en el conflicto del Pérsico," Novedades, November 6, 1990; "Duro golpe a la OLP,” La Jornada.

50 E. Galeano, "Preguntitas," La Jornada, January 15, 1991.

51 G. Martre, "La tormenta debe seguir,” El Universal, January 22, 1991.

52 H. Hernández Ascencio, “Scuds: 'los que van a morir te saludan', El Sol de Mediodía, February $1,1991$. 
The global questioning of the State of Israel and its ideological paradigm surpassed criticism of a particular government, the army's actions, or the ruling coalition's political platform. Israel was recursively seen as a "racist country that operated outside any legal framework" and as the soil for "the movement of international gangsters." 53

Overlapping at the meaning-making level between anti-Israelism and antiZionism can be observed through analogies, parallels, and metaphors that point to the Holocaust inversion: the West Bank Wall was conceived out of a great strategic plan, the slow and sustained "extermination," "this time, without gas chambers." 54

The Nakba as Israel's “expulsion” of 700,000 Palestinians-which was preceded by "ethnic cleansing"-has a straight parallel with the Holocaust: the word Nakba denotes the "oldest and most prolonged Holocaust" in contemporary history as a result of the creation of an "illegal Zionist state." 55 They are compared to the Nazi perpetrators toward their ancestors in Europe, to an extermination camp into which they only allowed the water and food necessary for the survival of the Palestinian inhabitants. ${ }^{56}$ The Nazi-Fascist wall locked up Palestinians alive in "ghettos" (the author uses the term within quotation marks). As part of the anti-American and anti-imperialist discourse that emphasizes the alliance between the US and Israel, the walls at the West Bank and at the USAMexico border were compared, though only the former was seen as a "genocide."

\section{Re-shaping the tropos: its Transnational Projection}

In its avatars, the various meanings of that negative tropos' transferred were reinforced through a historical and now transregional and transnational cultural/ ideological code that characterizes the media, broad sectors of intellectuals, and public figures. Thus, anti-Zionism, anti-Israelism, and antisemitism-in their singularity and convergences-become transnational phenomena that connect peo-

53 U. Pipitone, “El Golfo,” La Jornada, February 24, 1991.

54 J. Steinsleger, “¿Cuándo caerá el muro?,” La Jornada, January 6, 2010, https://www.jornada. com.mx/2010/01/06/opinion/015a2pol.

55 J. Steinsleger, "Palestina: orígenes de la nakbaa," La Jornada, May 5, 2010, https://www. jornada.com.mx/2010/05/05/opinion/021a1pol.

56 Cf. Á. Guerra Cabrera, “Gaza, prisión no, campo de exterminio,” La Jornada, November 22, 2012, https://www.jornada.com.mx/2012/11/22/opinion/028a1mun. 
ple across countries, regions, and continents through the flow of theories and prejudices and the political agenda of social movements at the local, regional, and global levels. As stated, we distinguish the critique of Israel and its policies from stands that recover, use, and extend anti-Jewish images.

Worldwide, and in Latin America, after many years of an unsettled IsraelPalestine conflict, today's opposition to Israel ceased to be a code for some other evil. Alongside more open antisemitism by right-wing xenophobic groups-though not exclusively-the subculture of the Left, even of the centerLeft, cannot be seen in its stance toward Israel as a side-issue, ripe to serve as a cultural code. ${ }^{57}$

Increased hostility toward Israel appears to be globally articulated, transcending the national boundaries of countries. It is a "transnational ideological package" that symbolizes the struggle against globalization and US hegemony. Thus, simultaneously, the anti-Zionist discourse points to a larger camp that transcends Latin American countries' national boundaries. Globalization and transnationalism magnify positive and negative trends that have been built over time.

Latin America has incorporated global cycles of political opportunities and social conflicts, as evident in democratization and de-democratization, centralization, civic citizenship, and ethnic allegiances, collective affirmation and the individualization of rights. Multiculturalism and new claims for recognition of primordial identities have also reinforced exclusion on ethnic grounds. While the scope for diversity broadens, Latin American societies also face severe risks of fragmentation and even de-structuring processes. The prevalence of historically complex relations with the United States and widespread dissatisfaction with globalization opened new opportunities for radical movements in the region.

Neo-liberal and growingly institutionalized citizenship regimes coexist with the corporatist and populist political forms, social mobilization, and plebiscitary democracy. Thus, the region experiences contradictory trends: increasing civic participation of social and political actors is threatened by exclusionary initiatives. The region experiences the transnationalization of prejudice. Interacting

57 Cf. Volkov, "Readjusting Cultural Codes"; Senkman, "Anti-Zionist Discourse of the Left in Latin America”; J. Bokser Liwerant and L. Senkman, "Diásporas y transnacionalismo: nuevas indagaciones sobre los judíos latinoamericanos hoy," in Judaica Latinoamericana VII, ed. M. Bejarano, F. F. Goldberg, and Y. Goldstein (Jerusalem: AMILAT, 2013), 11-71; J. Bokser Liwerant, "Anti-Semitism and Related Expressions of Prejudice in a Global World. A View from Latin America," in Measuring Antisemitism: An Expert Research Report in Progress, ed. Institute for the Study of Global Antisemitism and Policy and The Jewish People Policy Institute. 
with the discursive production and reproduction of negative symbols, antisemitism acquires new modalities of expression.

Social movements gained problematic protagonism. In the anti-globalization stream, the World Social Forum in Brazil in 2003 brought together swastikas and the peace sign, the rainbow flag and the blue and white UN symbol as visible images. The Malaysian prime minister referenced Jews who determine the currency level and bring about the collapse of currencies. ${ }^{58}$ Later, 157 organizations and social movements worldwide participated in the World Social Forum (WSF) held in Porto Alegre, Brazil, in November-December 2012. The meeting was "taken over" by organizations and NGOs from the US, Canada, South Africa, Europe, and Asia. Many Palestinian organizations also attended the forum. It was convened to support the Palestine cause and brought together non-governmental organizations, left-wing political groups, Arab federations based in Brazil, and both formal and informal social movements. This WSF meeting epitomizes transnational advocacy networks seeking the international recognition of Palestinian statehood claims at the UN through mass demonstrations and the use of social networks, in addition to the local media. Indeed, an extensive array of local social movements, international NGOs, and heterogeneous institutions within a transnational civil society used an anti-Zionist discourse globally. Advocacy for Palestine's legitimacy through anti-Zionist language that de-legitimizes Israel reflects the constituencies, ideological codes, and working procedures/mechanisms of transnational advocacy networks and global civil society. ${ }^{59}$ Unlike developments in previous decades, current social and political actors with antiZionist stands are not confined solely to political parties and organizations. In contrast to the 1960s, in the new millennium, anti-Zionism has become a mobilization myth for action and political identification.

A new constellation that redefines the links between collective identities, cultural and ideological trends and the public sphere's boundaries has given birth to scenarios in which anti-Jewish prejudices become entrenched in progressive claims. It is both a legacy of the anti-Western cultural code and new representations of the axis Jewish-Zionist state. It problematically meets, embraces, and re-elaborates Jewish anti-Zionist and post-Zionist voices.

Concurrently, different social movements attract vast middle-class sectors, including Jews and the Jewish community, as civic participants of the national arena. Liberal democratic policies have further enhanced this trend. Indeed, Jew-

58 Cf. M. Strauss, “Antiglobalism's Jewish Problem,” Foreign Policy, no. 139 (2003): 58-67.

59 Cf. D. F. Wajner, "In Quest of Legitimacy: Framing Battles in the Arab Spring and the Arab League’s Legitimation Role” (MA Thesis, Hebrew University of Jerusalem, 2013). 


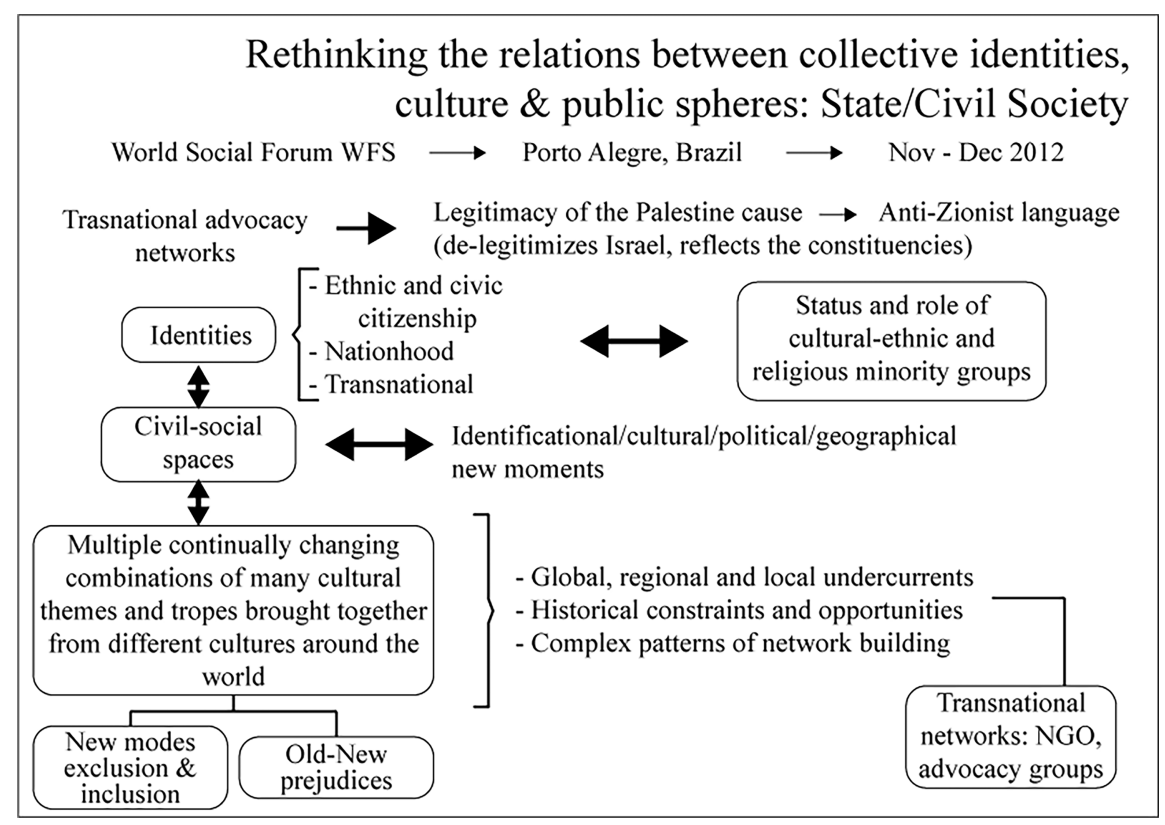

Image 8: Rethinking the relations between collective identities, culture, and the public sphere.

ish individuals have increasingly entered the political sphere and assumed highranking public offices, while organized Jewish communities have reached prominent roles due to increased citizenship participation. Thus, the twofold recognition and erosion of a national ethnic narrative and the increased recognition of minorities based on religious and ethnic grounds confer increasing visibility and legitimacy to Jewish communities.

Following a profound polarization of the Palestinian-Israeli conflict, the end of the Cold War and bipolarity positively affected the region, leading to the normalization of relations with both the Palestinians and Israel, although founded on an equidistance basis. In the 1990s, motivated by the signing of the Oslo Accords (1993), formal diplomatic missions of the new Palestinian Authority opened in several countries. ${ }^{60}$

60 Chile (1992), Brazil (1993), Mexico (1995), Argentina and Colombia (1996), and Peru (1998). A few years after the signing of the Chilean-Palestinian Memorandum for Scientific, Technical, Cultural and Educational Cooperation (June 1995), Chile opened the first diplomatic Latin American representation in Ramallah (April 1998). 
Simultaneously, as an ideological stance among Latin American diplomacy, anti-Zionism lost its virulence as a resource to rhetorically attack Israel and was replaced instead by pragmatic considerations in countries such Brazil, Mexico, and Nicaragua. Meaningfully, all Latin American countries except Cuba voted on December 16, 1991, in favor of UN Resolution 46/86, revoking the resolution that equated Zionism with racism. ${ }^{61}$ However, throughout the following years, the major ALBA countries (Venezuela, Bolivia, Ecuador, Nicaragua, and Cuba) severed diplomatic ties with Israel. They all voiced harsh anti-Zionist and antiIsrael criticism. In a reconfigured world system, the Venezuelan regime under Hugo Chávez (1998-2013) became a Latin American proxy of the Iranian state and its hatred of Jews under Maduro. Geopolitical considerations played an essential part in making both Zionism and Israel Venezuela's enemies. Thus, part of the government's animosity toward Jews might have been due to his determination to win Tehran's favor. This explanation also seems to hold when analyzing the ALBA countries' anti-Zionist position, the anti-US bloc led by Chavismo. ${ }^{62}$

Regarding the policies of Latin American countries toward the Middle East, a contradictory picture develops. On the one hand, globalization has brought new opportunities to the region, both in international relations and world markets. On the other hand, the stalled Israel-Palestine peace process has given way to the emergence of regional leaderships and their positioning as emergent superpowers in the international arena.

The globalization of the Palestinian-Israeli conflict will likely continue if certain conditions are present, such as the continued stagnation of the peace process, the eruption of new cycles of violence in the Middle East, the strengthening of Islamic radical groups in countries that are now experiencing political turmoil, the presence of neo-populist governments in the region and the particular interactions between strategic decisions of international, regional and national and local activists. ${ }^{63}$

61 Cf. Senkman, "Anti-Zionist Discourse of the Left in Latin America”; C. Baeza and E. Brun, "La diplomacia chilena hacia los países árabes entre posicionamiento estratégico y oportunismo comercial,” Estudios Internacionales 44, no. 171 (2012): 61-85; C. Baeza, “América latina y la cuestión palestina (1947-2012)," Araucaria 14, no. 28 (2012): 111-31.

62 Cf. L. Roniger, Antisemitism, Real or Imagined? Chávez, Iran, Israel, and the Jews (Jerusalem: Hebrew University of Jerusalem, 2009).

63 Cf. J. Bokser Liwerant, "El conflicto palestino israelí. Recurrencias históricas, nuevos dilemas," in El conflicto en Gaza e Israel: una visión desde América Latina, ed. M. Férez Gil and S. Sberro (México: Senado de la República, Comisión de Biblioteca y Asuntos Editoriales, LXI Legislatura, 2009), 95-124. 
The criticism of Israel's policies-as grounded as it may be-continues to overlap with prejudiced arguments that recover, re-elaborate, and project comprehensive anti-Zionism and various contents and expressions of antisemitism. As seen, even though they are singular phenomena, and have explicit and implicit prejudices and negative expressions, they overlap at the meaning-making level as well as in the more concrete realm of argumentative convergences.

Tropos-building and praxis meet and are mutually nourished. University settings became academic fora of solidarity with Palestine, and it is expressed in extreme anti-Zionist stances. Among the many, in the one held in 2017 at the National Autonomous University of Mexico (UNAM), the criticism of Israel incorporated hard-core antisemitic prejudices. As the Boycott, Divestment and Sanctions movement (BDS) was promoted, expressions like "dyslexic biblical exegesis," "a vicarious avocation" and "a dangerous delusion" were unexpectedly uttered. The transnational dimension of prejudice may be best appreciated in the words of Columbia professor Hamid Dabashi:

Half a century of systematic maiming and murdering of another people has left its deep marks on the faces of these people, the way they talk, the way they walk, the way they handle objects, the way they greet each other, the way they look at the world. There is an endemic prevarication to this machinery, a vulgarity of character that is bone-deep and structural to the skeletal vertebrae of its culture. ${ }^{64}$

Current expressions of anti-Zionism and its antisemitic tones are much more than an ideational-cultural struggle for equality and human rights. In contrast to the past, social, and political actors with anti-Zionist stands are not confined solely to political parties and leftist organizations.

The interfacing between national, regional, and global dimensions, antisemitism and the differentiation of its contemporary expressions are framed by the pluralization of social and political actors and the relevance of the media as a source of collective representation in the public sphere. Diffuse and latent prejudices, veiled and structural, as well as those rejected in the official semantics but evident in the rhetoric of individuals and of collective sectors are part of contemporary reality both in Latin America and elsewhere. The configuration of the anti-Jewish tropos has been analyzed here through conceptual constructions and metaphors that objectify antisemitic imagination. These expressions show the geological cumulative levels of stereotypes. As they are connected to a certain

64 H. Dabashi, "For a Fistful of Dust: A Passage to Palestine," Al-Ahram Weekly, September 23-29, 2004, https://web.archive.org/web/20080112011322/http:/weekly.ahram.org.eg/2004/ 709/cu12.htm. 
imaginary, they can also be traced in concrete images-the powerful world of caricatures that we have analyzed elsewhere. ${ }^{65}$ Produced and reproduced discursively, as that which has concrete impact on individual and collective behavior, exhibits structural trends, as a longue durée historical phenomenon with recurrences and changes.

The historical course of tropos-building, which does not necessarily translate into discriminatory practices, needs to be contextualized within each country's political culture and status of human rights. Understanding its strength emerges as a sine qua non requirement when attempting to account for the actual extent of antisemitic danger derived from discursive and symbolic violence.

Judit Bokser Liwerant is Full Professor of Political Science and Sociology at the Universidad Nacional Autónoma de México and a Distinguished Visiting Professor at the Hebrew University of Jerusalem. She is member of the Mexican Academy of Sciences. Her research specializes in Political Theory, Contemporary Jewish life in Latin America, modernity and Jewish responses (migration and Zionism), diaspora, transnationalism, and antisemitism. She has published widely in all of these research areas.

\section{References}

\section{Primary Sources}

Allaz, Tomás Gerardo. "Estatuto de animales para los no judíos.” Excelsior, December 1975. Allaz, Tomás Gerardo. “Israel, víctima de sí mismo.” Excelsior, December 1975. Armendáriz, Antonio. “¿Semitismo o sionismo?” Novedades, December 1, 1975. Bellinghausen, Hermann. “¿Razas arrasadas?” La Jornada, January 24, 1991. Chávez Hayhoe, Salvador. "Sionismo y racismo." El Universal, November 27, 1975. Galeano, Eduardo. "Preguntitas.” La Jornada, January 15, 1991. García Jaime, R. "El judío.” Uno más uno, February 4, 1991. Guerra Cabrera, Ángel. “Gaza, prisión no, campo de exterminio.” La Jornada, November 22, 2012. https://www.jornada.com.mx/2012/11/22/opinion/028a1mun.

Hernández Ascencio, H. "Scuds: ‘los que van a morir te saludan'.” El Sol de Mediodía, February 1, 1991.

Huerta Cruz, José Luis. “Antisionismo no es antisemitismo.” El Universal, November 27, 1975. Huerta Cruz, José Luis. "No sólo discriminación semántica del racismo.” El Universal, December 29, 1975. Ilanes, E. "Elitismo pero no racismo." Novedades, November 22, 1975.

65 Cf. J. Bokser Liwerant, "Mexico in a Region Under Change," Journal for the Study of Antisemitism 3, no. 1 (2011): 27-49. 
Lara Barragán, Antonio. “El judaísmo internacional.” El Universal, December 6, 1975. Martre, G. "La tormenta debe seguir." El Universal, January 22, 1991.

Ministerio de Relaciones Exteriores. Memoria del Ministerio de Relaciones Exteriores presentada al Congreso Nacional. Imprenta Nacional, 1938.

N. N. "Antisionismo no es antisemitismo." El Universal, December 11, 1975.

N. N. "Autorizan al ejército israelí disparar contra palestinos que arrojen piedras." El Día, December 12, 1990.

N. N. “'Completa tolerancia religiosa hay en Israel,' afirma Rabasa.” El Nacional, December 8, 1975.

N. N. "Duro golpe a la OLP, la muerte de Abu lyad; era considerado un héroe por los palestinos." La Jornada, January 16, 1991.

N. N. "Llegó Rabasa a Tel Aviv, 'para discutir cualquier malentendido', dijo." Excelsior, December 5, 1975.

N. N. "Los malos entendidos." El Universal, December 6, 1975.

N. N. "Ofrenda de Rabasa ante la tumba del 'padre del sionismo'." El Nacional, December 6, 1975.

Pipitone, U. "El Golfo." La Jornada, February 24, 1991.

Segovia, E. "Palabras de México en la filosofía y en la ONU.” El Día, February 27, 1991.

Steinsleger, José. “¿Cuándo caerá el muro?” La Jornada, January 6, 2010. https://www.jorna da.com.mx/2010/01/06/opinion/015a2pol.

Steinsleger, José. "Palestina: orígenes de la nakba." La Jornada, May 5, 2010. https://www. jornada.com.mx/2010/05/05/opinion/021a1pol.

Téllez Girón, José María. “Judaísmo, sí; sionismo, no.” El Día, December, 1975.

Villegas, Abelardo. "Balance político de 1975. Candidato, grupos de presión, Israel." Excelsior, December 22, 1975.

Zea, Leopoldo. "El sionismo y las trampas del pacifismo." Novedades, December 23, 1975.

Zea, Leopoldo. "Israel en el conflicto del Pérsico." Novedades, November 6, 1990.

Zea, Leopoldo. “¿Qué es por fin el sionismo?” Novedades, December 16, 1975.

\section{Secondary Sources}

Baeza, Cecilia. "América latina y la cuestión palestina (1947-2012)." Araucaria 14, no. 28 (2012): 111-31.

Baeza, Cecilia, and Elodie Brun. "La diplomacia chilena hacia los países árabes entre posicionamiento estratégico y oportunismo comercial." Estudios Internacionales 44, no. 171 (2012): $61-85$.

Bokser Liwerant, Judit. "Anti-Semitism and Related Expressions of Prejudice in a Global World. A View from Latin America." In Measuring Antisemitism: An Expert Research Report in Progress, edited by Institute for the Study of Global Antisemitism and Policy and The Jewish People Policy Institute.

Bokser Liwerant, Judit. "Correction to: Past and Present of Latin American Jewry: A Conceptual Pathway." Contemporary Jewry 38, no. 2 (2018): 203.

Bokser Liwerant, Judit. "El conflicto palestino israelí. Recurrencias históricas, nuevos dilemas." In El conflicto en Gaza e Israel: una visión desde América Latina, edited by 
Manuel Férez Gil and S. Sberro, 95-124. México: Senado de la República, Comisión de Biblioteca y Asuntos Editoriales, LXI Legislatura, 2009.

Bokser Liwerant, Judit. "El México de los años treinta: cardenismo, inmigración judía y antisemitismo." In Xenofobia y xenofilia en la historia de México, siglos XIX y XX: Homenaje a Moisés González Navarro, edited by Moisés González Navarro and Delia Salazar Anaya, 379-415. México: SEGOB, Instituto Nacional de Migración, Centro de Estudios Migratorios; Instituto Nacional de Antropología e Historia; DGE Ediciones SA de CV, 2006.

Bokser Liwerant, Judit. "Fuentes de legitimación de la presencia judía en México: el voto positivo de México a la ecuación sionismo-racismo." In Judaica Latinoamericana III, edited by Margalit Bejarano and Efraim Zadoff, 319-50. Jerusalem: Hebrew University of Jerusalem; AMILAT, 1997.

Bokser Liwerant, Judit. "Identidades colectivas y esfera pública: judíos y libaneses en México.” In Árabes y judíos en Iberoamérica similitudes, diferencias y tensiones, edited by Raanan Rein, 323-58. Sevilla: Fundación Tres Culturas, 2008.

Bokser Liwerant, Judit. “Mexico in a Region Under Change." Journal for the Study of Antisemitism 3, no. 1 (2011): 27-49.

Bokser Liwerant, Judit. “Thinking Multiple Modernities from Latin America's Perspective: Complexity, Periphery and Diversity." In Varieties of Multiple Modernities: New Research Design, edited by Gerhard Preyer and Michael Sussman, 177-205. Leiden: Brill, 2016.

Bokser Liwerant, Judit. "Sinopia and Pentimenti.” Wistrich Lecture, Jerusalem, 2018.

Bokser Liwerant, Judit, and Leonardo Senkman. "Diásporas y transnacionalismo: nuevas indagaciones sobre los judíos latinoamericanos hoy.” In Judaica Latinoamericana VII, edited by Margalit Bejarano, Florinda F. Goldberg, and Yossi Goldstein, 11-71. Jerusalem: AMILAT, 2013.

Bokser Liwerant, Judit, and Yael Siman. "Antisemitism in Mexico and Latin America: Recurrences and Changes." In Antisemitism in North America: New World, Old Hate, edited by Steven K. Baum, Neil J. Kressel, Florette Cohen-Abady, and Steven Leonard Jacobs, 21-173. Leiden: Brill, 2016.

Bourdieu, Pierre. Razones prácticas: Sobre la teoría de la acción. Barcelona: Anagrama, 2007. Busbridge, Rachel. "Israel-Palestine and the Settler Colonial 'Turn': From Interpretation to Decolonization.” Theory, Culture \& Society 35, no. 1 (2018): 91-115.

Chazan, Robert. Medieval Stereotypes and Modern Antisemitism. Berkeley: University of California Press, 1997.

Cohen, Ben. "The Persistence of Anti-Semitism on the British Left." Jewish Political Studies Review 16, nos. $3 / 4$ (2004): 157-69.

Cotler, Irwin. "Human Rights and the New Anti-Jewishness: Sounding the Alarm.” Jerusalem: The Jewish People Policy Planning Institute, 2002.

Dabashi, Hamid. "For a Fistful of Dust: A Passage to Palestine." Al-Ahram Weekly, September 23-29, 2004. https://web.archive.org/web/20080112011322/http:/weekly.ahram.org.eg/ 2004/709/cu12.htm.

DellaPergola, Sergio. "Jewish Perceptions of Antisemitism in the European Union, 2018: A New Structural Look." Analysis of Current Trends in Antisemitism - ACTA 40, no. 2 (2020): $1-86$.

Deutsch, Sandra McGee. Counterrevolution in Argentina, 1900-1932: The Argentine Patriotic League. Lincoln: University of Nebraska Press, 1986. 
Edelman, Samuel. "Antisemitism and the New/Old Left." In Not Your Father's Antisemitism: Hatred of the Jews in the Twenty-First Century, edited by Michael Berenbaum, 271-94. St. Paul: Paragon House, 2008.

Edthofer, Julia. "Israel as Neo-Colonial Signifier? Challenging De-Colonial Anti-Zionism." Journal for the Study of Antisemitism 7, no. 2 (2015): 31-51.

Eisenstadt, Shmuel N. "Latin America and the Problem of Multiple Modernities." In Shifting Frontiers of Citizenship: The Latin American Experience, edited by Mario Sznajder, Carlos A. Forment, and Luis Roniger, 43-54. Leiden: Brill, 2013.

Eisenstadt, Shmuel N. "Multiple Modernities." Daedalus 129, no. 1 (2000): 1-29.

Finchelstein, Federico. La Argentina fascista: Los orígenes ideológicos de la dictadura. Buenos Aires: Editorial Sudamericana, 2008.

Fischel, Jack R. “The New Anti-Semitism.” Virginia Quarterly Review 81, no. 3 (2005): $225-34$.

García Sebastiani, Marcela, ed. Fascismo y antifascismo, Peronismo y antiperonismo: Conflictos políticos e ideológicos en la Argentina (1930-1955). Madrid/Frankfurt am Main: Vervuert, 2006.

Goldhagen, Daniel J. The Devil That Never Dies: The Rise and Threat of Global Antisemitism. New York: Little, Brown, 2016.

González, Genaro María. “Amenazas Norteamericanas. Falta de bases históricas y legales.” Excelsior, November 17, 1975.

González, Genaro María. “Diplomacia caprichosa: ¿hay algo que perdonar?” Excelsior, December 15, 1975.

Grosfoguel, Ramón. "Human Rights and Anti-Semitism After Gaza." Universitas Humanística, no. 68 (2009): $157-77$.

Hirsh, David. “Anti-Zionism and Antisemitism: Cosmopolitan Reflections.” Occasional Papers, Yale Initiative for the Interdisciplinary Study of Antisemitism (YIISA), New Haven, 2007.

Hirsh, David. "Hostility to Israel and Antisemitism: Toward a Sociological Approach." Journal for the Study of Antisemitism, no. 5 (2013): 1401-22.

Klug, Brian. "The Collective Jew: Israel and the New Antisemitism." Patterns of Prejudice 37, no. 2 (2003): $117-38$.

Klug, Brian. "Is Europe a Lost Cause? The European Debate on Antisemitism and the Middle East Conflict." Patterns of Prejudice 39, no. 1 (2005): 46-59.

Lesser, Jeff. Welcoming the Undesirables: Brazil and the Jewish Question. Berkeley: University of California Press, 1995.

Lewis, Bernard. Semites and Anti-Semites: An Inquiry into Conflict and Prejudice. New York: Norton, 1999.

Lloyd, David. "Settler Colonialism and the State of Exception: The Example of Palestine/Israel." Settler Colonial Studies 2, no. 1 (2012): 59-80.

Lomnitz-Adler, Claudio. El antisemitismo y la ideología de la Revolución mexicana. Mexico City: Fondo de Cultura Económica, 2010.

Lomnitz-Adler, Claudio. Exits from the Labyrinth: Culture and Ideology in the Mexican National Space. Berkeley: University of California Press, 1992.

Matas, David. Aftershock: Anti-Zionism and Anti-Semitism. Toronto: Dundurn, 2005.

Mignolo, Walter D. "The Global South and World Dis/Order." Journal of Anthropological Research 67, no. 2 (2011): 165-88. 
Powell, Lawrence N. Troubled Memory: Anne Levy, the Holocaust, and David Duke's Louisiana. Chapel Hill: University of North Carolina Press, 2002.

Quijano, Aníbal, and Immanuel Wallerstein. "La americanidad como concepto, o América en el moderno sistema mundial." Revista Internacional de Ciencias Sociales 134, no. 4 (1992): 583-91.

Raab, Earl. “Antisemitism, Anti-Israelism, Anti-Americanism.” Judaism 51, no. 4 (2002): 387-96.

Reisigl, Martin, and Ruth Wodak. Discourse and Discrimination: Rhetorics of Racism and Antisemitism. London: Routledge, 2005.

Roniger, Luis. Antisemitism, Real or Imagined? Chávez, Iran, Israel, and the Jews. Jerusalem: Hebrew University of Jerusalem, 2009.

Senkman, Leonardo. "Anti-Zionist Discourse of the Left in Latin America: An Assessment." In Reconsidering Israel-Diaspora Relations, edited by Eliezer Ben-Rafael, Judit Bokser Liwerant, and Yosef Gorny, 309-33. Leiden: Brill, 2014.

Senkman, Leonardo. El antisemitismo en la Argentina. Buenos Aires: Centro Editor de América Latina, 1986.

Strauss, Mark. “Antiglobalism's Jewish Problem.” Foreign Policy, no. 139 (2003): 58-67.

Taguieff, Pierre-André. La nueva judeofobia: Israel y los judios, desinformación y antisemitismo. Barcelona: Gedisa, 2009.

Taguieff, Pierre-André. Rising from the Muck: The New Anti-Semitism in Europe. Chicago: Ivan R. Dee, 2004.

Veracini, Lorenzo. "The Other Shift: Settler Colonialism, Israel, and the Occupation.” Journal of Palestine Studies 42, no. 2 (2013): 26-42.

Volkov, Shulamit. "Antisemitism as a Cultural Code: Reflections on the History and Historiography of Antisemitism in Imperial Germany." The Leo Baeck Institute Yearbook 23, no. 1 (1978): $25-46$.

Volkov, Shulamit. "Readjusting Cultural Codes: Reflections on Anti-Semitism and Anti-Zionism." Journal of Israeli History 25, no. 1 (2006): 51-62.

Wajner, Daniel F. "In Quest of Legitimacy: Framing Battles in the Arab Spring and the Arab League's Legitimation Role.” MA Thesis, Hebrew University of Jerusalem, 2013.

Whitehead, Laurence. "Latin America as a 'Mausoleum of Modernities'." In Latin America: A New Interpretation, edited by Laurence Whitehead, 23-68. New York: Palgrave Macmillan US, 2006.

Wieviorka, Michel. The Lure of Anti-Semitism: Hatred of Jews in Present-Day France. Leiden: Brill, 2007.

Zipperstein, Steven J. "Historical Reflections on Contemporary Antisemitism." In Contemporary Antisemitism: Canada and the World, edited by Michael R. Marrus, Derek J. Penslar, and Janice Gross Stein, 52-63. Toronto: University of Toronto Press, 2005. 